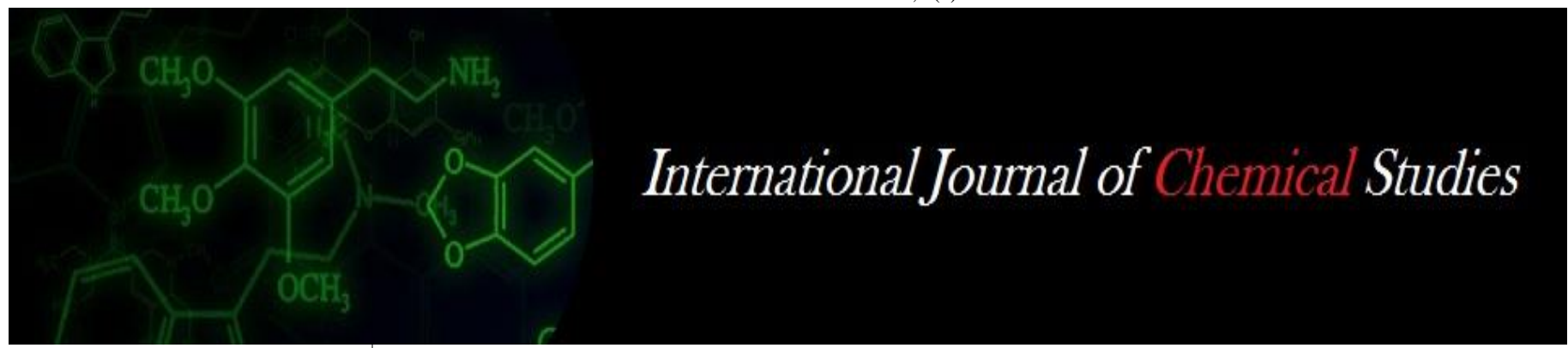

P-ISSN: 2349-8528

E-ISSN: 2321-4902

www.chemijournal.com

IJCS 2020; 8(3): 2644-2646

(C) 2020 IJCS

Received: 22-03-2020

Accepted: 24-04-2020

Nandita Paul

Department of Entomology,

Indira Gandhi Krishi

Vishwavidyalaya, Raipur,

Chhattisgarh, India

Sonali Deole

Department of Entomology,

Indira Gandhi Krishi

Vishwavidyalaya, Raipur,

Chhattisgarh, India
Corresponding Author: Nandita Paul

Department of Entomology,

Indira Gandhi Krishi

Vishwavidyalaya, Raipur,

Chhattisgarh, India

\section{Seasonal incidence of fall army worm, Spodoptera frugiperda (Smith) infesting maize crop at Raipur (Chhattisgarh)}

\author{
Nandita Paul and Sonali Deole
}

DOI: https://doi.org/10.22271/chemi.2020.v8.i3al.9613

\begin{abstract}
The field experiment were conducted at Research Cum Instructional Farm at IGKV, Raipur (C.G.) during kharif 2018, to know the seasonal incidence of fall army worm, Spodoptera frugiperda infesting maize crop. Fall army worm, Spodoptera frugiperda appeared during $37^{\text {th }}$ SMW i.e. $2^{\text {nd }}$ week of September with a mean population of 0.12 larva/plant. The peak population were observed in the fourth week of September with a mean population of 0.56 larva/plant. Thereafter, the population declined gradually and reached to a minimum level of 0.16 larva/plant during $4^{\text {th }}$ week of October ( $\left.42^{\text {nd }} \mathrm{SMW}\right)$.

The correlation between fall army worm, Spodoptera frugiperda and abiotic parameters during kharif 2018 results indicated that the population demonstrated a significant positive correlation with maximum temperature $(\mathrm{r}=0.586)$.
\end{abstract}

Keywords: Correlation, maize, incidence, fall army worm

\section{Introduction}

Maize or corn (Zea mays L.) is a crop of global importance, which holds a unique position in world agriculture. Maize belongs to the family of Poaceae, originated from South America, from where it was taken to all parts of the world.

In India maize production estimated about 20240 tonnes in kharif and 8470 tonnes in rabi. Although in 2018-19 production were decreased by 20220 tonnes in kharif and 7580 tonnes in rabi (Indiastat). In Chhattisgarh, it is well informed in an area of 226.79 hec. With productivity of $2458 \mathrm{~kg} / \mathrm{hec}$. of kharif season. Although 74.45 ha. Area and $1950 \mathrm{~kg} / \mathrm{ha}$. Productivity of rabi season in 2017-18 (Annualreport 2017-18).

Although 139 insect pests cause varying degree of damage to maize crop, only about a dozen of these are quite serious and require control measures like maize stalk borer, pink stem borer, and shoofly are the insects of national importance while the armyworm, jassids, thrips, pyrilla, grasshoppers, white grub, cut worms, hairy caterpillars, termites, and the leaf miner are more serious regional level insect pests (NIPMP, 2001). Amongst the most serious pests shoot fly and maize stem bore, (Chilo partellus Swinhoe, Sesamia inferens Walker) occurs as serious pests in India (Manjunath, 2013).

The fall army worm is a lepidopteran pest that feeds in large numbers on leaves and stems of more than 80 plant species, causing major damage to economically cultivated grasses such as maize, rice, sorghum, sugarcane but also other vegetable crops and cotton. The literature on this pest is extensive (Ashley et al., 1989) ${ }^{[2]}$.

On maize, if $5 \%$ of seedlings are cut or $20 \%$ of whorls of small plants (during the $1^{\text {st }} 30$ days) are infested, it is recommended that an insecticide be applied (King and Saunders, 1984) ${ }^{[4]}$; on sorghum the pest threshold level is regarded as one (or two) larvae per leaf whorl and two per head (Pitre, 1985) ${ }^{[5]}$.

The studies on seasonal incidence of insect pests and their natural enemies of maize crop and their correlation with the weather parameters provide basic information about seasonal occurrence of insect pests and their natural enemies. This provides an opportunity for the development of management strategies significant for the control of these pests. 


\section{Materials and Methods}

A field experiment was conducted at Research Cum Instructional Farm at IGKV, Raipur, (C.G.) during kharif 2018 under field condition to know the occurrence of insect pests on maize. The popular hybrid genotype was raised and maintained without insecticide application to study the occurrence of major insect pests on maize in relation to abiotic factors viz., maximum temperature, minimum temperature, relative humidity (morning and evening), wind velocity and sunshine hours.

To determine the seasonal incidence of insect pests on maize crop, weekly populations were recorded on randomly selected twenty five plants from four corners and center starting from 15 days after germination to the late stage of the cropping season.

The occurrence of fall armyworm, Spodoptera frugiperda (Smith) was observed by devasting sampling of 25 randomly selected plants at five different locations of plot. Then, the symptoms seen in foliar damage of plant and count the number of larvae of Spodoptera frugiperda at seven days interval starting from 15 days after germination till harvest of the crop.

The data was statistically analyzed by subjecting to the correlation between weather parameters and the population of insect pests which were determined using the Karl Pearson's coefficient of correlation formula:

$$
r=\frac{\sum X Y-\frac{\sum X \sum Y}{N}}{\sqrt{\left(\sum X^{2}-\frac{\left(\sum X\right)^{2}}{N}\right)\left(\sum Y^{2}-\frac{\left(\sum Y\right)^{2}}{N}\right)}}
$$

Where,

$\mathrm{R}_{\mathrm{xy}}=$ Simple correlation coefficient

$\mathrm{X}=$ Variable i.e. abiotic component. (Average temperature, relative humidity and total rainfall)

$\mathrm{Y}=$ Variable i.e. mean number of insect pests per plant
$\mathrm{N}=$ Number of observations.

The correlation coefficient (r) values were subjected to the test of significance using t-test:

$t=\frac{r_{x y} \sqrt{n-2}}{\sqrt{1-r_{x y}^{2}}}$

$\sim$ t n-2 d.f.

Where,

$\mathrm{r}=$ Correlation Coefficient

$\mathrm{n}=$ No. of observations

The calculated t-value obtained was compared with correlation coefficient table value at $5 \%$ and $1 \%$ level of significance.

\section{Results and Discussion}

Fall army worm, Spodoptera frugiperda appeared during $37^{\text {th }}$ SMW i.e. $2^{\text {nd }}$ week of September with a mean population of 0.12 larva/plant. The population slowly increased and reached to its peak in the fourth week of September with a mean population of 0.56 larva/plant. When, the maximum atmospheric temperature, minimum atmospheric temperature, and relative humidity were $32.9{ }^{\circ} \mathrm{C}, 25^{\circ} \mathrm{C}$ and 76 per cent, respectively. Thereafter, the population declined gradually and reached to a minimum level of 0.16 larva/plant during $4^{\text {th }}$ week of October ( $42^{\text {nd }}$ SMW).

The results indicated that the larvae of fall army worm population exhibited a non-significant negative correlation with total rainfall $(\mathrm{r}=-0.32)$, evening relative humidity $(\mathrm{r}=-$ 0.233 ) and wind velocity $(r=-0.341)$. While, it was showed significant positive correlation with maximum temperature $(\mathrm{r}=0.586)$. The regression equation being $(\mathrm{Y}=0.071 \mathrm{x}-2.099)$ indicating that with an increase in $1^{\circ} \mathrm{C}$ temperature there will be increase in population of larvae/plant by 0.071 per cent.

Table 1: Seasonal incidence of fall army worm, Spodoptera frugiperda (Smith) infesting maize genotype KSCH-972 during, kharif 2018.

\begin{tabular}{|c|c|c|c|c|c|c|c|c|}
\hline $\begin{array}{c}\text { SMW } \\
\text { No. }\end{array}$ & $\begin{array}{c}\text { Average no. of larvae of fall army } \\
\text { worm/plant }\end{array}$ & $\begin{array}{c}\text { Max. Temp. } \\
(\mathbf{0} \mathbf{C})\end{array}$ & $\begin{array}{c}\text { Min. Temp. } \\
(\mathbf{0} \mathbf{C})\end{array}$ & $\begin{array}{c}\text { Rain Fall } \\
(\mathbf{m m})\end{array}$ & $\begin{array}{c}\text { RH (\%) } \\
\text { Mor. }\end{array}$ & $\begin{array}{c}\text { RH (\%) } \\
\text { Eve. }\end{array}$ & $\begin{array}{c}\text { Wind Velocity } \\
(\mathbf{K m} / \mathbf{h})\end{array}$ & $\begin{array}{c}\text { Sun Shine } \\
(\mathbf{h o u r s})\end{array}$ \\
\hline 33 & 0 & 30.3 & 25.3 & 101.2 & 94 & 79 & 4.1 & 2.9 \\
\hline 34 & 0 & 29.0 & 24.6 & 60.4 & 93 & 79 & 5.5 & 0.6 \\
\hline 35 & 0 & 28.3 & 24.1 & 275.0 & 96 & 86 & 6.8 & 0.2 \\
\hline 36 & 0 & 29.2 & 23.9 & 30.2 & 93 & 57 & 0.5 & 1.1 \\
\hline 37 & 0.12 & 32.6 & 25.1 & 0.0 & 90 & 55 & 2.2 & 6.4 \\
\hline 38 & 0.32 & 31.0 & 24.1 & 32.8 & 92 & 68 & 3.5 & 3.6 \\
\hline 39 & 0.56 & 32.9 & 25.0 & 11.0 & 93 & 59 & 1.2 & 7.8 \\
\hline 40 & 0.56 & 34.0 & 23.8 & 0.0 & 91 & 44 & 0.7 & 8.0 \\
\hline 41 & 0.44 & 32.4 & 22.8 & 0.0 & 87 & 51 & 2.8 & 7.1 \\
\hline 42 & 0.16 & 33.4 & 21.3 & 0.0 & 89 & 40 & 1.0 & 8.5 \\
\hline 43 & 0 & 32.9 & 18.9 & 0.0 & 86 & 48 & 1.1 & 8.3 \\
\hline 44 & 0 & 31.0 & 19.6 & 0.0 & 86 & 49 & 2.6 & 9.3 \\
\hline 45 & 0 & 32.3 & 20.1 & 0.0 & 86 & 49 & 1.8 & 8.7 \\
\hline \multicolumn{2}{|c|}{ Correlation coefficient (r) } & $0.586^{*}$ & 0.312 & -0.327 & 0.026 & -0.233 & -0.341 & 0.350 \\
\hline
\end{tabular}

*Significant at $5 \%$ level of significance

**Significant at $1 \%$ level of significance

SMW: Standard Meteorological Week

Similarly, Ahir et al., (2017) ${ }^{[1]}$ who recorded the Spodoptera litura followed by Spodoptera frugiperda population exhibited a significant negative correlation with relative humidity $(r=-0.647)$ and total rainfall $(r=0.536)$ while, non significant correlation with mean atmosphere temperature. The minimum temperature, relative humidity and rainfall proving negative relationship with population of $S$. litura infesting groundnut crop. Similarly, Yadav et al., (2015) ${ }^{[6]}$ in black gram also reported that population of $S$. litura showed non- significant negative correlation with rainfall and wind velocity while temperature (minimum and maximum), relative humidity (morning and evening) and sunshine 
showed a non significant positive correlation. Similarly, Brahman et al., 2018 [3] in soybean also reported that population of $S$. litura showed significant correlation with maximum temperature $(\mathrm{r}=0.663)$, whereas negative significant correlation was noticed with rainfall $(\mathrm{r}=-0.570)$.

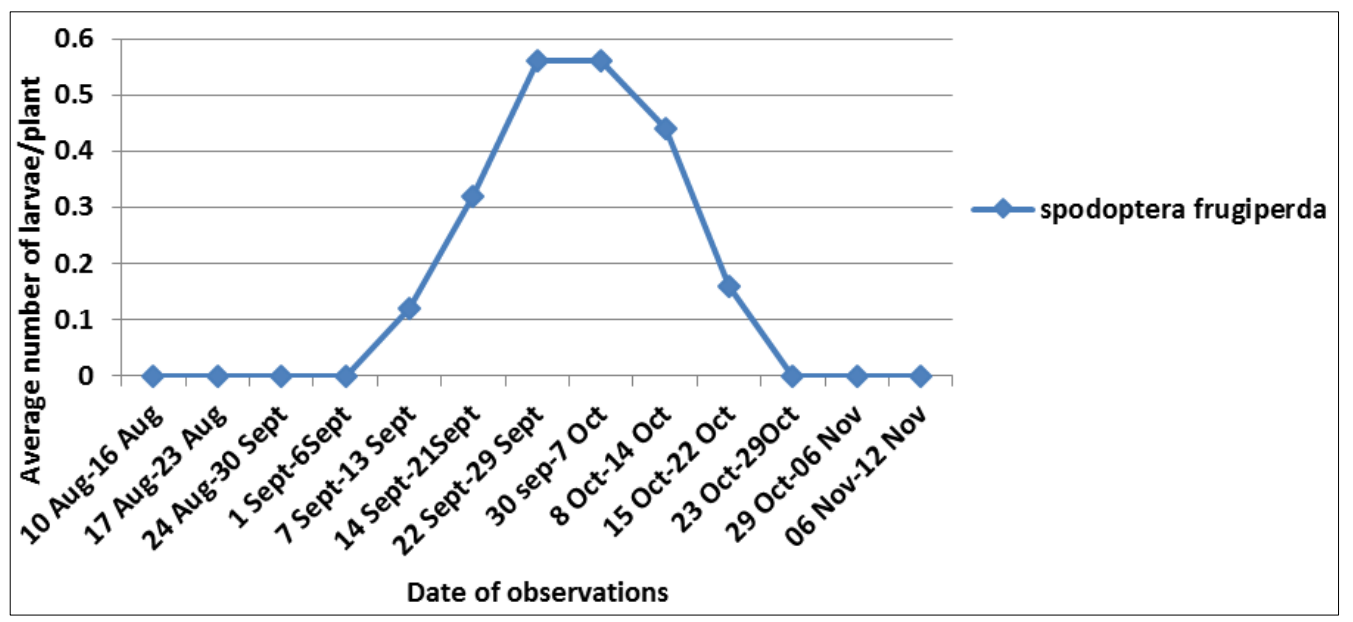

Fig 1: Mean population of fall army worm, Spodoptera frugiperda during, kharif 2018.

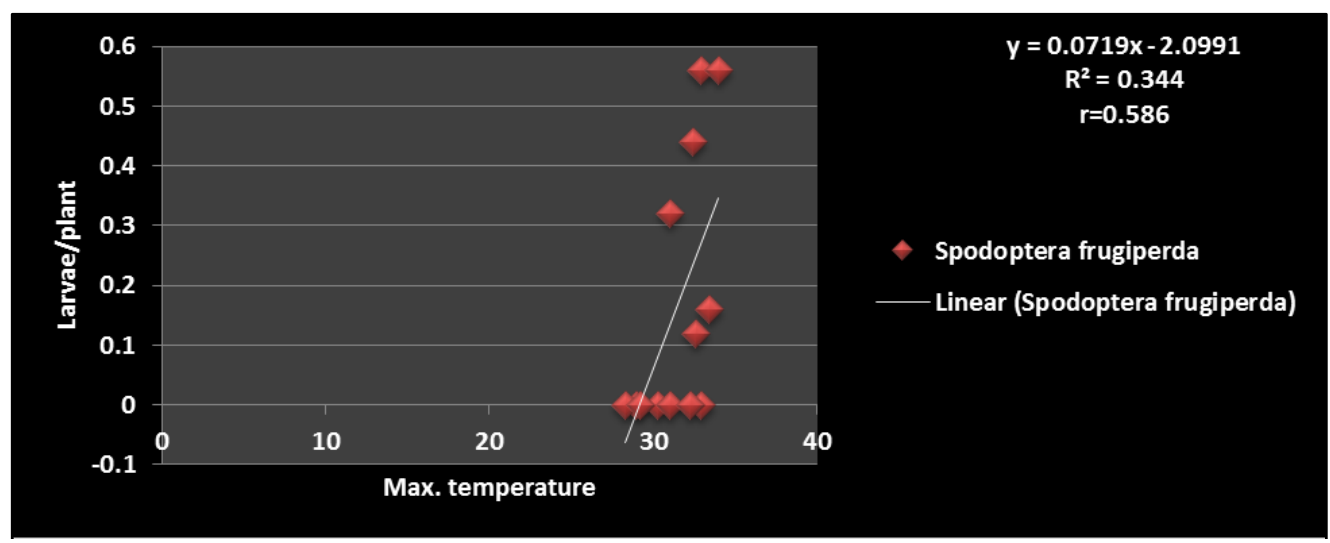

Fig 2: Regression line between weather parameters and population build-up of Spodoptera frugiperda.

\section{Conclusion}

The peak period of fall army worm with a mean population of 0.56 larva/plant were seen during $40^{\text {th }}$ SMW, respectively. Whereas, the fall army worm population showed significant positive correlation with maximum temperature $(\mathrm{r}=0.586)$.

\section{References}

1. Ahir KC, Saini A, Rana BS. Seasonal incidence of tobacco caterpillar, infesting on groundnut. International Journal of pure and Applied Bioscience. 2017; 5(2):267271.

2. Ashley TR, Wiseman BR, Davis FM, Andrews KL. The fall armyworm: bibliography. Florida Entomologist. 1989; 72:152-202.

3. Brahman SK, Awasthi AK, Shailendra Singh. Studies on insect pest of soybean (Glycine max) with special reference to seasonal incidence of lepidopteran defoliators. Journal of Pharmacognosy and phytochemistry. 2018; 7(1):1808-1811.

4. King and Saunders. Spodoptera frugiperda Center for Systematic Entomology, Gainesville, Florida. 1984; 5:34.

5. Pitre HN, DB Hogg. Development of the fall armyworm on cotton, soybean and corn. J Georgia Entomol. Soc. 1988; 18:182-187.

6. Yadav S, Agnihotri M, Bisht RS. Seasonal incidence of insect-pests of blackgram, Vigna mungo (Linn.) and its correlation with abiotic factors. Agric. Sci. Digest. 2015; 35(2):146-148. 